\title{
用語解説
}

\section{カーネル法（Kernel Method）}

カーネル法(Kernel Method)とは，主にパターン認識の分野で広く利用されている非線形処理を実現するた めの手法であり, SVM (Support Vector Machine)や主成分分析, 正準相関分析といった線型モデルで表現され る手法に広く組み込まれ利用されている。

カーネル法では, データを高次元の特徵空間に写像し写像先での内積計算を行う。高次元空間における線形 モデルの適用は，実質的にもとの空間での非線形処理と等価になるため，カーネル法を線形モデルに組み合わ せることにより実質的に非線形モデルへと拡張することができる.

カーネル法の名前の由来は, 特徵空間中のデータの内積を計算するためにカーネル関数を利用していること であり，このカーネル関数を用いることで入力空間から特徴空間への写像計算を理論的な裏付けの基で回避し ている。これはカーネルトリックと呼ばれ, 特徴空間でのべクトルを陽に扱わずにデータ点の内積計算を実現

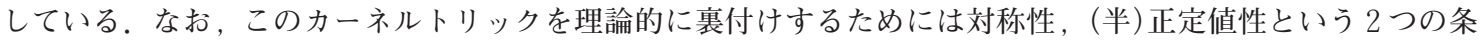
件を満たすカーネル (正定值カーネル)関数を利用する必要がある.

カーネル関数は特徴空間上での 2 つのデータ間の内積を表しており，データ間の「類似度」を表していると捉 えることができる。カーネルトリックの重要な点は, 高次元における内積の計算が, 入力空間のカーネル関数 によって行える点にあり, カーネル関数として対象の類似性を適切に表現するものを選択することにより, 特 徵空間への写像に指定した類似度を反映することができる。これは, カーネル法の持つ重要な特徴であり，ユー ザーが「類似度」という比較的, 定義しやすい形で対象問題に対する知識をモデルに組み込むことができること を意味している.

近年, カーネル法の応用分野はますます広がっており, 物体認識, テキスト分類, 時系列予測, バイオイン フォマティクスなど非常に多岐にわたっている.

（室蘭工業大学 しくみ情報系領域 渡邊 真也）

\section{VerilogHDL}

HDL (Hardware Description Language) とはハードウェア記述言語と呼ばれ，ハードウエアを記述する言語 である。ここでのハードゥエアは論理回路のことを示しており，アナログ回路を含まない．この言語を使って 開発できるHDLで設計できるLSIの代表的なものにFPGA(Field Programmable Gate Array) と呼ばれるデバイ スがあり，現在ではALTERA社とXilinx社のものがほとんでである. FPGAはHDLでプログラミングするように 設計でき，さらにPC上のシミュレータソフトでシミュレーションしてから実装することができる．主に有名な HDLとしてAHDL, VerilogHDL, VHDLがある. AHDLは, ALTERA社のFPGAのみ対応していた言語であり， 現在使っている技術者も少ない.VerilogHDLは，C言語のような記述であるため初心者でもとっかかりやす い.FPGAだけでなくASIC設計でも主流になりつつある。VHDLはパッケージファイルと呼ばれる情報ファイ ルを併用して設計を行う。パッケージファイルには, 遅延時間, 電圧, 電流, 配線距離などさまざまな情報を 含んでいる。このため他よりも性能が良いといわれているが, その反面設計が複雑になりやすい。一方 VerilogHDLでは論理記述だけで，コンパイラソフトなどのツール側が対象デバイス固有の情報を持っており， これを自動的に利用する。このため論理記述が容易で扱いやすい。また，VerilogHDLは同期レジスタを扱う設 計に優れて扬り，同期型ロジック回路の設計に扔いて相性が良い。このためカメラ信号やバスコントロールな ど , クロックを基準にして動作する回路を設計する場合に扱いやすい言語である.

(高知工科大学 工学部電子・光システム工学科 星野 孝総) 